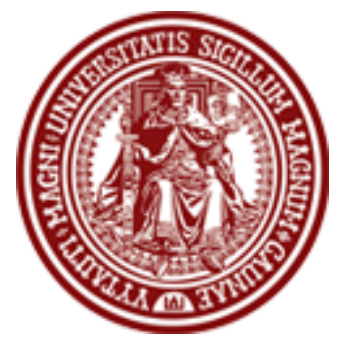

BALTIC JOURNAL OF LAW \& POLITICS

VOLUME 6, NUMBER 2 (2013)

ISSN 2029-0454

http://www.degruyter.com/view/j/bjlp

Cit.: Baltic Journal of Law \& Politics 6:2 (2013): 50-74

DOI: $10.2478 / \mathrm{bjlp}-2013-0011$

\title{
DEVELOPMENT OF PERFORMANCE MANAGEMENT REFORMS IN LITHUANIAN PUBLIC SECTOR
}

\author{
Mindaugas Kaselis \\ Doctoral Candidate \\ Vytautas Magnus University Faculty of Political Science and Diplomacy \\ (Lithuania) \\ Contact information \\ Address: S. Daukanto str. 28, LT-44246 Kaunas, Lithuania \\ Phone: +370 37327871 \\ E-mail address: m.kaselis@pmdf.vdu.It
}

Received: November 18, 2013; reviews: 2; accepted: December 16, 2013.

\begin{abstract}
The article presents result-based performance management in the public sector and challenges for its formation. The attention is paid to the fact that despite the managerial character, this is a perspective with political implications. Before the result-based performance management in Lithuania is analyzed, the American experience has been presented, where almost each new administration of the President (since President Lyndon B. Johnson) has introduced systemic novelties with regard to the development of management on the federal level. Lastly, qualitative research data is used to present the attitudes of Lithuanian civil servants and politicians to the components of performance management, while the programmes of the political parties for the Lithuanian Seimas (Parliament) in 2012-2016 help to reveal the attitudes of the present party in power towards the components of performance management.
\end{abstract}

\section{KEYWORDS}

Performance management, performance information, public sector, public servant, politician, political dimension 


\section{INTRODUCTION}

The management directed to performance results cannot be separated from the organization of private business as it helps to achieve the main goal - to gain profit for companies. Although the public sector is organized using different principles, it also endeavors to produce better performance results, alongside the production and provision of public goods, suitable redistribution of public resources, democratic regime and public availability of public goods. First of all, this is due to public pressure: more educated citizens as taxpayers demand from the public government better services, the performance results, which would satisfy them, and responsibility and accountability of civil servants. Thus the society forms demand for various monitoring and accountability systems of results, creation of servicing standards, quality management systems, and preparation of surveys of receivers of public services. However, the politicians should also be interested in the development of initiatives of result-based management and to support them at least because of their rhetorical attractiveness. This would help them to attract more electors. Indeed, almost any politician would be admired if he stated that the public institutions would act according to the clear, transparent tasks consequent of politically defined objectives (starting with the Government/Ministries); that such performance would be assessed according to the measurable and predictable performance indicators, and that all the information on activity results in the form of reports or presentations would be publicly available to the society. The scientific literature presents the possibility to communicate the result-based management ideas to various society groups as symbolic benefit of performance management to the politicians, and it is even more important than the instrumental benefit that is identified to accountability. ${ }^{1}$ However, the elements of performance management are included into the Lithuanian political debates and agendas relatively rarely. For example, performance management was applied on the central level in Lithuania only in 2000 with the beginning of the process of strategic planning. ${ }^{2}$ It was initiated by the Conservative Government led by the then Prime Minister Andrius Kubilius. The main purpose of performance management's launching was "to bridge the gap between falling budget revenues as a result of a fiscal crisis and increasing

\footnotetext{
${ }^{1}$ Donald P. Moynihan, The Dynamics of Performance Management: Constructing Information and Reform (Washington: Georgetown University Press, 2008), p. 68.

2 Vitalis Nakrošis, Strateginis valdymas Lietuvoje: ar turime rezultatu vyriausybę? (Strategic Management in Lithuania: Do We Have Result-Based Government?) (Vilnius: Vilniaus universitetas, 2008), p. 16.
} 
governmental commitments owning to its accession to the EU and NATO". ${ }^{3}$ The further more significant initiatives of performance management appeared only eight years later and by the efforts of essentially the same people. In 2008 the Conservative Party returned to the power (called TS-KD) as part of a coalition and the Office of Prime Minister (present Office of the Government) in 2009-2012 implemented the project "Improvement of the Result-Based Management (VORT)", which aim was to implant the elements of result-oriented management based on evidence in the public sector. First of all, the methodical means and technical tools had to be created (for example, monitoring system of performance results). As VORT presentation shows "the project has contributed to the enhancement of performance of the Government and subordinate institutions by helping to improve performance monitoring and accountability, functional analysis, and programme evaluation, as well as decision impact assessment." ${ }^{4}$ Thus, the 15 th Government of Republic of Lithuania was interested in foreign performance management's practice and "one of the main objectives for public management reform during 2009-2012 was enhancing the results based culture". ${ }^{5}$

However, the adaptation of performance management does not mean its implementation, and the implementation (i.e. usage of performance information (results) for improvement of internal processes in the institutions, making of better solutions and accounting of civil servants to direct supervisors, politicians and society) is actually the one to determine the success of the utilization of performance management. According to Wouter Van Dooran, "[...] the history of performance measurement and performance management in the twentieth century has been a history of [performance information] use.[...] If we want to study the successes and failures of performance movements, we have to study the use of performance information." ${ }^{\prime 6}$ To say it simply, the presence of management tools does not mean their proper, if any, usage. Besides, it is always possible to question whether such tools are suitable and sufficient. For example, even in the USA, which has a great deal of experience of application of performance management in the public sector, there are some gaps seen in the adaptation by the archon in this area. Donald P. Moynihan calls the adaptation process "partial", because the managers of public sector (civil servants) are not provided with enough freedom to

3 Vitalis Nakrošis, "Reforming Performance Management in Lithuania: Towards Result-Based Management": 53; in: B. Guy Peters, eds., Mixes, Matches and Mistakes: New Public Management in Russia and the Former Soviet Republics (Budapest: Open Society Institute, 2008).

4 VORT project, Government of the Republic of Lithuania // http://www.Irv.It/en/activities/vortproject/vort-project1/ (accessed November 23, 2013).

${ }^{5}$ Rimantas Rauleckas, et al., "Public Administration Reforms during Fiscal Crisis in Lithuania: Perceptions of Senior Civil Servants," Viešoji politika ir administravimas (Public Policy and Administration) 12 (3) (2013): 353.

${ }^{6}$ Wouter Van Dooran, "Nothing New Under the Sun? Change and Continuity in the Twentieth-Century Performance Movements": 22; in: Wouter Van Dooran and Steven van de Walle, eds., Performance Information in the Public Sector (Basingstoke: Palgrave Macmillan, 2008). 
control the financial and human resources independently from central authority, and as the result the fundamental principle of new public management-"let managers manage"-is not ensured. ${ }^{7}$

In 2012 the governing majority in the Lithuanian Parliament changed. It was formed by new political parties; still the degree to which they were engaged with result-based management is unclear. Thus this article is used to learn the extent to which performance management is important to the Lithuanian politicians, and whether and how the political parties use performance management as rhetorical tool. For this purpose the programs of the present parties in the coalition government for the Parliament's election in 2012 are reviewed.

It should be noted that during the Seimas' term of 2008-2012 the VORT project was not the only attempt to adapt performance management in Lithuania. The best example could be the Improvement Conception of Civil Service approved by the 15th Government of the Republic of Lithuania on 02 June 2010. Among five shortages of civil service and its legal regulation indicated in this document of the Lithuanian Government, three are related to the gaps of adaptation of result-based performance management: a) "the activity of the civil servants is not directed to results $[\ldots] "$; b) "the leading civil servants have limited possibilities to manage the human resources flexibly [the principle "let managers manage" is not secured]"; and c) "the leading civil servants do not have sufficient liability for the performance results of the institution". ${ }^{8}$ Moreover, among seven development (improvement) principles of civil service indicated in the draft conception of 25 February 2010, four are related to the result-based performance management: a) "orientation to performance results and "public needs"; b) "implementation of agreements regarding performance results"; c) "[...] civil service based on results $[\ldots]$ "; and d) "bigger flexibility of staff management". ${ }^{9}$ This presumes that the $15^{\text {th }}$ Lithuanian Government of the previous cadence related the entire improvement of civil service system mainly to the dimension of result-based management. These ideas about how to reform the civil service are important not only to society, but also to civil servants, as they are the one who have to work in the new management environment. Therefore the question arises whether the civil servants of various institutions understood this "message" of previous government and identified the

\footnotetext{
7 Donald P. Moynihan, supra note 1, p. 39-47.

8 Lietuvos Respublikos vyriausybès nutarimas dèl valstybès tarnybos tobulino koncepcijos patvirtinimo (Resolution of the Government of the Republic of Lithuania on the Authorization of the Civil Service Improvement Strategy Conception), Resolution of the Government of the Republic of Lithuania No. 715 (June 2, 2010) // http://www3.Irs.It/pls/inter3/dokpaieska.showdoc_l?p_id=375123\&p_query=\&p_tr2= (accessed November 25, 2013).

9 Lietuvos Respublikos vyriausybès projektas "Valstybès tarnybos tobulinimo koncepcija" (Project of the Government of the Republic of Lithuania of the Civil Service Improvement Strategy Conception), Project by the Government of the Republic of Lithuania No. 10-695-01 (February 25, 2010) // http://www.muitinesprofsajunga.It/index.php/skelbimai-praneimai/150-valstybs-tarnybos-tobulinimokoncepcijos-projektas (accessed November 25, 2013).
} 
previous reforms with the perspective of result-based performance management, and what their attitude to this managerial dimension is. This article will provide answer to this question as well, utilizing 50 interviews conducted in 2011 with civil servants of various Lithuanian authorities. The interviews were conducted while implementing the scientific research project "Public Service Reform in the Light of Good Governance" financed by the Lithuanian Research Council, contract No. MIP $33 / 2010$ (the interviews were made by the members of the project - Saulius Pivoras, Remigijus Civinskas, Arvydas Mikalauskas, Ernesta Visockytè and Mindaugas Kaselis). As the $15^{\text {th }}$ Government only partially succeeded in implanting its ideas about performance management, the opinions of civil servants about the result-based management would be useful to the new government as well.

The main issue of this article is whether public servants supported political view (vision, aims) of adaption of performance management reforms in Lithuania initiated by the 15th Government of the Republic of Lithuania. Secondly, this article inquires whether the 16th Government of the Republic of Lithuania is also planning to move on performance management reforms (by having different visions), as well as almost every U.S. president administration has its own political vision of performance management reforms on federal level. Thus the object of this article is the attitudes of civil servants and politicians towards the result-based performance management, or, put simply, towards the adaptation of management according to the results in Lithuania. In parallel, the objective of this article is to present the attitudes of civil servants and politicians towards the dimension of management according to the results in the background of reforms of civil service and (non)engagement of the governing majority of present central government for performance management on the background of election to the Lithuanian Seimas in 2012.

Research methods: analysis of scientific literature, analysis of official documents, qualitative research.

Previous research. Estonian researches Kulli Nomm and Tiina Randma-Liiv, reviewing recent studies of performance management from Central and Eastern European countries, state that "the performance management - and more particularly, performance measurement - component of these reform attempts has not received sufficient academic attention so far [...]; [existed studies] focus on the introduction of particular performance based management tools are rather descriptive and have ended up with contradictory conclusions". ${ }^{10}$ In addition to these observations, some Lithuanian performance management studies should be

\footnotetext{
${ }^{10}$ Kulli Nomm and Tiina Randma-Liiv, "Performance Measurement and Performance Information in New Democracies: A Study of the Estonian Central Government," Public Management Review 14 (7) (2012): 860.
} 
mentioned as relevant for adoption of performance management reforms in Lithuania. Dangis Gudelis (2007) in his doctoral dissertation "Municipal Performance Measurement Models and Opportunities of their Implementation in Lithuania" examines the organization of performance measurement systems in Lithuania municipalities and the condition to improve them. ${ }^{11}$ Additionally, scholar Vitalis Nakrošis (2008) tried to find an answers at the following questions about performance management reforms at central Lithuanian governing level: what is the most important goals of performance management and how should be reformed performance management in Lithuania? ${ }^{12}$ Furthermore, Vitalis Nakrošis and Žilvinas Martinaitis (2011) seek to explain adaption of performance management techniques by analyzing managerial authority. ${ }^{13}$

Also, it may be noted that Lithuanian civil servants opinions towards civil service reform in 2009-2012 and civil servants' attitudes toward use of management tools in civil service reform are relatively broadly researched by others Lithuanian scholars. For instance, the studies focus on separate processes and aspects of civil service reform as performance contracts with top civil servants (R. Civinskas, 2011) ${ }^{14}$, issues of legal regulation of public service and status of public servants (E. Visockytè, 2011) ${ }^{15}$, civil servants' performance assessment by results (M. Kaselis and S. Pivoras, 2012) ${ }^{16}$, the need for civil service reform (E. Visockytè, 2012) ${ }^{17}$, improving the competitive selection for civil service (S. Pivoras, $2012)^{18}$, reform trends, reform results and results oriented culture (R. Rauleckas, E. Gaulè, R. Šnapštienè, V. Morkevičius, L. Šarkutè and J. Buškevičiūtè, 2013) ${ }^{19}$.

11 Dangis Gudelis, Savivaldybiu veiklos matavimo modeliai ir ju igyvendinimo galimybès Lietuvoje (Municipal Performance Measurement Models and Opportunities of their Implementation in Lithuania), doctoral dissertation (Vilnius: Mykolas Riomeris University, 2007).

12 Vitalis Nakrošis, supra note 3.

13 Vitalis Nakrošis and Žilvinas Martinaitis, "Introduction"; in: Vitalis Nakrošis and Žilvinas Martinintis, eds., Lithuanian Agencies and Other Public Sector Organisations: Organisation, Autonomy, Control and Performance (Vilnius: Vilnius University, 2011).

${ }_{14}$ Remigijus Civinskas, "Can a Senior Civil Servant Adapt to Managing by Contract? Reform and Civil Servants' Preferences in Lithuanian Government," Baltic Journal of Law \& Politics 4 (2) (2011).

${ }_{15}$ Ernesta Visockyte, "Civil Service and Civil Servants in Lithuania: Issues of Regulation and Status," Baltic Journal of Law \& Politics 4 (2) (2011).

${ }_{16}$ Mindaugas Kaselis and Saulius Pivoras, "Valstybès tarnautoju veiklos vertinimas pagal rezultatus: taikymo iššūkiai Lietuvoje" (Civil Servants' Performance Assessment by Results: Challenges of Implementation in Lithuania), Viešoji politika ir administravimas (Public Policy and Administration) 11 (1) (2012).

17 Ernesta Visockytè, "Lietuvos valstybès tarnybos reformos poreikis valstybès tarnautoju požiūriu" (The Need for Civil Service Reform in Lithuania: Civil Servants' Position), Viešoji politika ir administravimas (Public Policy and Administration) 11 (3) (2012).

${ }^{18}$ Saulius Pivoras, "Konkursinès atrankos i Lietuvos valstybès tarnyba tobulinimas gero valdymo iššūkiu perspektyvoje" (Improving the Competitive Selection for Civil Service in Lithuania with Respect to the Challenges of Good Governance), Viešoji politika ir administravimas (Public Policy and Administration) 11 (3) (2012).

19 Rimantas Rauleckas, et al., supra note 5. 


\section{PERformance manAgement IN THE PUBLIC SECTOR: THE POLITICAL DIMENSION}

At first glance performance management may look like a simple managerial tool, but it is not so, as it has a political character contained in its nature, as well. This managerial tool helps to implement the accountability of the institutions of the public sector to the and politicians for the results of the performed activity. Therefore the essence of the performance management in the institutions of public sector is the continuous collection, recording, analysis and measurement of information on performance in order to be able to account to the elected officials and society for the done works. The accountability of performance management is expressed inside the executive branch, as well. For example, the territorial unit is accountable to the central institution and other institutional relations may be expressed through the mechanism of contracts. However, the usage of information may be not only external - for the purpose of accounting - but also internal, ${ }^{20}$ when the information on performance is used in the institutions of public sector in order to improve management, decision-making or for the purpose of studying. It should be noted that the civil servants may be rewarded or receive sanctions according to their performance results, using the grounds known beforehand.

Still in order to collect information on performance, the employees of institutions in public sector have to know what data have to be collected and are considered to be important. Here the political mechanism of performance management "switches on", because ideally the society forms its needs and public "orders" for the politicians, which have to be transformed by the latter to smaller objectives and tasks set for the institutions of executive branch. At the same time the indexes of expected performance results and assessment criteria are formed. They serve as starting point for collection and measurement of information on performance. However, there the political leadership is also important, because it is more difficult to form the performance objectives and indicators in public sector than in private sector, where the most important aims are effectiveness and profit. The results of much wider range are expected from the organizations of public sector. For example, one of the biggest challenges is the orientation to the performance outcomes and effect, which is not so simple to control. Let us say that the main problem in the area of Lithuanian communication policy is safety on the roads, because according to the EU statistics, Lithuania has 100 fatalities for one

20 Gerhard Hammerschmid, Steven Van de Walle, and Vid Stimac, "Internal and External Use of Performance Information in Public Organizations: Results From an International Survey," Public Money \& Management 33 (4) (2013): 262. 
million inhabitants, and that is the highest indicator in the entire EU. ${ }^{21}$ Therefore the indicator of performance outcomes could be a smaller number of people killed on the roads, but this aim is also affected by the choices of public institutions and activity in the area of inputs-activities-outcomes: proper resources (financial, human resources, etc.) have to be selected in the communication area, as well as certain activities (more frequent patrols on roads, installation of speed measuring instruments in the most dangerous places, etc.) and certain results or output of direct activity, and their indexes - for example, maintenance of the roads (indicators - number of asphalted roads per year, number of lightened streets, etc.).

Thus the mechanism of supply-demand is important in performance management, according to Wouter Van Dooran. ${ }^{22}$ The demand for the information on performance is usually formed by the politicians (although not necessarily) as the main users of information, who consolidate the requirements for it in the legal acts, whereas the supply is related to the preparation of information on performance by civil servants. In the absence of the political engagement to form the demand for information on performance, the democratic component may "fluctuate", because various researchers have noticed weak places in the process of performance management anyway, when the civil servants "adjust" to the performance management systems. Sometimes even manipulations happen (for example, unrealistic objectives of activity are set) - this is called "gaming"23 or the paradoxes of performance management ${ }^{24}$ in the scientific literature. Therefore the aim of this article is to learn whether the Lithuanian politicians of the governing majority care about performance management. On the other hand, it is also necessary to know the attitudes of civil servants towards the result-based reforms, as the "[public sector] organization may [not only] supply information and thereby create a demand" ${ }^{25}$, especially in case of weaker political leadership with regard to performance management.

\footnotetext{
${ }^{21}$ European Commission's press release "Road safely: EU reports lowest ever number of road deaths and takes first step towards an injuries strategy" // http://europa.eu/rapid/press-release_IP-13-236_en.htm (accessed November 1, 2013).

22 Wouter Van Dooran, Performance Measurement in the Flemish Public Sector, Doctoral dissertation (Leuven: Katholike Universiteit, 2006), p. 32.

${ }^{23}$ Gwyn Bevan and Christopher Hood, "What's Measured is What Matters: Targets and Gaming in the English Public Health Care System," Public Administration 84 (3) (2006): 517-538.

24 Sandra Van Thiel and Frans L. Leeuw, "The Performance Paradox in the Public Sector," Public Performance \& Management Review 25 (3) (2002): 267.

${ }^{25}$ Wouter Van Dooran, supra note 22, p. 32.
} 


\section{THE U.S. EXPERIENCE IN PERFORMANCE MANAGEMENT: POSSESSION OF POLITICAL VISION}

From U.S. President Lyndon B. Johnson (1963-1969) forward, nearly every U.S. President's administration has a new approach to federal performance management, and generally to the establishment of a clear and widely spread performance and the budgetary system or framework. Matthew Dull argues that "each is an analytical technique that embraces one of the major management concepts of its era with the goal of improving the quality and the influence of policy decisions; each also builds on the analytical resources and perceived failings that are the legacies of previous initiatives" ${ }^{\prime 26}$. It should be noted that almost every administration had a separate name for the performance management system. U.S. President George W. Bush even initiated a separate document called the President's management agenda, mainly for existing performance management problems and the resulting response to the administration of the State. Such institutionalized (64 pages) visions and ideas in performance management are not only a form of guidance by which public authorities need to act, but also a commitment to the citizens of the country, because according to George W. Bush "[...] the Administration is dedicated to ensuring that the resources entrusted to the federal government are well managed and wisely used. We owe that to the American people"27.

It should be noted that even at the beginning of the twentieth century, among the U.S. public authorities, especially in the case of New York Bureau of Municipal Research, an effort to link the public resources to performance and many features for the performance measurement is observed. Moreover, it is reflected in the modern practice: "measuring of input, output, and results; attempting to make government more productive; making reports comparable among communities; and focusing on allocation and accountability" ${ }^{\prime 28}$, Daniel W. Williams notes. An important moment in the U.S. history of the performance management is considered in 1949 Hoover Commission report "Organization of the Executive Branch of the Government", which establishes a new approach to the performance budgeting: "[...] For the first time, the commission's recommendations acknowledged that the value of performance budgeting consisted not in gathering data as an end in itself,

\footnotetext{
${ }^{26}$ Matthew Dull, "Why PART? The Institutional Politics of Presidential Budget Reform," Journal of Public Administration Research and Theory 16 (2006): 188.

27 The President's Management Agenda (2002), Office of Management and Budget // http://www.whitehouse.gov/sites/default/files/omb/assets/omb/budget/fy2002/mgmt.pdf (accessed September 1, 2012).

${ }^{28}$ Daniel W. Williams, "Measuring Government in the Early Twentieth Century," Public Administration Review 63 (6) (2002): 643
} 
but rather in using that information to inform decisions"29. The Hoover Commission report is likely to have influenced and further practical systems launches at U.S. federal level (firstly, "Planning, programming and budgeting system" or PPBS) linking performance measurement, the performance information and budget decisions.

Although the PPBS is usually identified with President Lyndon B. Johnson, his Administration did not construct it; rather, they captured and distributed it in all of the federal structures. Since 1961 the U.S. Defense Department has been successfully applied the initiative. Lyndon B. Jonhson decided to introduce PPBS in order to sustain its "Great Society agenda" and PPBS as instrument "was focused on comparing and integrating policies; it was designed to coordinate and rationalize a burgeoning array of social policies" ${ }^{\prime 30}$. Besides, the President's choice to apply the PPBS led to having clear goals, identifying urgent goals, managing those goals most efficiency at the least coast and measuring the program's performance. ${ }^{31}$

"Management by objectives" (MBO) was supported and initiated by U.S. President Richard Nixon in 1973. The advantage of this model is its orientation not only to outputs but to outcomes as well, because "agency heads would be accountable for achieving presidential objectives of national importance; managers within an agency would be held accountable for objectives set jointly by supervisors and subordinates [...] but efforts were also made to define performance as the results of federal spending - what would today be called 'outcomes'"132. Thus, MBO was an important tool to implement the objectives of the President and agencies.

In the meantime, "Zero based-budgeting" (ZBB) in 1977 was suggested by U.S. President Jimmy Carter (and after 1979 it became mandatory for all U.S. federal authorities), who claimed that it was successful technique in the state of Georgia (where he performed the duties of the Governor) to improve the performance. ${ }^{33}$ This model is exclusive in that it "requires that every year policy makers assume nothing about the budget and start from an evaluation of all"34 and "agencies were expected to set priorities based on the programme results that could be achieved at alternative spending levels"35, however "ZBB failed to

29 Terry F. Buss, Nathaniel J. Buss, and Evan Hill, "Evidence in Public Management: A Comparative perspective": 131; in: Anna Shillabeer, Terry F. Buss, and Denise M. Rousseau, eds., Evidence - Based Public Management: Practices, Issues, and Prospects (New York: M. E. Sharpe, 2011).

${ }^{30}$ Matthew Dull, supra note 26: 196.

31 William F. West, Program Budgeting and the Performance Movement: The Elusive Quest for Efficiency in Government (Washington: Georgetown University Press, 2011), p. 20-21.

32 Wouter Van Dooren, Geert Bouckaert and John Halligan, Performance Management in the Public Sector (London and New York: Routledge, 2010), p. 42.

${ }^{33}$ F. Stevens Redbum, Robert J. Shea, Terry F. Buss, and Ednilson Quintanilla, "Performance-Based Management: How Governments Can Learn from Experience": 9; in: F. Stevens Redbum, Robert J. Shea, and Terry F. Buss, eds., Performance Management and Budgeting: How Governments Can Learn from Experience (New York: M. E. Sharpe, 2008).

${ }^{34}$ Terry F. Buss, Nathaniel J. Buss, and Evan Hill, supra note 29: 132.

35 Wouter Van Dooren, Geert Bouckaert, and John Halligan, supra note 32, p. 42. 
recognize the practical limits of agencies' ability to manage excessive performance information and the ultimately political nature of budgetary processes" ${ }^{\prime 36}$.

President Bill Clinton also had a distinctive approach to performance management. During his presidency they adopted "Government Performance and Result Act" (GPRA) in 1993, which marked a new reform trajectory in the U.S. history of performance management. This Act requires that US federal agencies in developing their institutional missions and a long term strategic plans have to consult the members of Congress and other stakeholders, establish annual performance goals which would focus on the outcome and in accordance with strategic plan, measure the results of their activities and achievements reports Congress. ${ }^{37}$ GPRA was a rather different performance management initiative from earlier ones. According to Beryl A. Radin, "Its enactment as legislation (rather than as executive orders) has built in a role for Congress that is relatively unusual into government reform efforts. In addition, GPRA's inclusion of pilot projects and its provision for a number of years for start-up are not the usual way for reform efforts to be conceptualized. ${ }^{\prime 38}$ On the other hand, this instrument at a practical level did not guarantee the use of performance information, because: "despite some lofty rhetoric and goals, GPRA had relatively modest requirements, asking only that agencies routinely create strategic goals and disseminate performance data" 39 .

G. W. Bush did not concede to his predecessors and during his presidency performance management has been implemented through a special mechanism Program Assessment Rating Tool (PART), the objective assessment of every federal government program. PART consists of a series of diagnostic (yes/no) questions (about 25-27, but it depended on the type of program) the program promoters (managers) who have been focused on four assessment dimensions: "program purpose and design" ("the weight of the assessment"-20\%), "strategic planning" $(10 \%)$, "program management" $(20 \%)$, the results of the program $(50 \%) .{ }^{40} \mathrm{It}$ should be noted that each assessed program has a plan to improve performance, for this reason federal agencies are obliged to improve not only results, but also the management. ${ }^{41}$ However, current President Obama rejected the PART model with a

\footnotetext{
${ }^{36}$ F. Stevens Redbum, Robert J. Shea, Terry F. Buss, and Ednilson Quintanilla, supra note 33: 9.

37 Alfred Ho, "GPRA After A Decade: Lessons From The Government Performance and Results Act and Related Federal Reforms," Public Performance \& Management Review 30 (3) (2007): 307.

38 Beryl A. Radin, Challenging Performance Movement: Acountability, Complexity and Democratic Values (Washington: Georgetown University Press, 2006), p. 119.

39 Donald P. Moynihan and Stephane Lavertu, "Does Involvement in Performance Management Routines Encourage Performance Information Use? Evaluating GPRA and PART," Public Administration Review 72 (4) (2012): 593.

40 Velda Frisco and Odd J. Stalebrink, "Congressional Use of the Program Assessment Rating Tool," Public Budgeting \& Finance 28 (2) (2008): 3.

41 "Expect Federal Programs to Perform Well, and Better Every Year," Expectmore.gov [Bush Administration's website for PART initiative; it is currently no active and has not been updated since president Obama refused PART] //
} 
different vision to performance management. The Presidential Administration has decided to concentrate on the most important and probably, according to the results of several studies, the weakest component of performance management i.e., the use of performance data in order to improve the Federal Government performance. ${ }^{42}$ Such a choice is fairly logical, because the practice of previous U.S. performance management initiatives weren't focused enough on performance information use. Moreover, why managers use performance information is characterized by scholars as "the big question" for performance management. ${ }^{43}$

\section{RESEARCH RESULTS: THE ATTITUDES OF CIVIL SERVANTS}

In 201150 interviews were conducted, the purpose of which was to learn the opinion of the representatives of public sector about the reforms in the Lithuanian civil service planned for 2009-2011. The respondents of the qualitative research may be divided into five groups. The largest group consisted of the managers of various levels from ministries, who had the status of civil servant (vice-ministers, chancellors, managers of departments or sections). It should be noted that only a few interviews were carried out with ordinary specialists from the ministries. The persons who contributed directly to the preparation of the reform of civil service (creation of ideas, management and coordination, technical implementation (preparation of the documents), should be attributed to the second group. The major part of the respondents of this smaller group compared with the first one consisted of the employees of the Office of Prime Minister (present Office of Government). Additionally, separate groups of respondents may be distinguished by stressing that the representatives of the institutions subordinate to the ministries took part in the qualitative research. Finally, the politicians (Minister and managers of the committees of the Lithuanian Seimas) were also selected as the respondents.

The initial question of the research ("In your opinion, what are the objectives of the civil service's reform and why is such reform necessary?") was asked to all the respondents without providing any detailed explanation as receiving independent considerations by the respondents was expected, how they saw the changes of public sector of that time and whether they were clear, acceptable, what

http://georgewbush-whitehouse.archives.gov/omb/expectmore/about.html (accessed October 22, 2013).

42 Kathryn Newcomer and F. Stevens Redburn, "Driving Improvement in Federal Policy Outcomes: Lessons for a New President": 264-265; in: Anna Shillabeer, Terry F. Buss, and Denise M. Rousseau, eds., Evidence - Based Public Management: Practices, Issues, and Prospects (New York: M. E. Sharpe, 2011).

43 Donald P. Moynihan and Sanjay K. Pandey, "The Big Question for Performance Management: Why Do Managers Use Performance Information?" Journal of Public Administration Research and Theory 20 (4) (2010): 849-850. 
shortages they saw and what was behind the new ideas. First of all, while interviewing one of the most active promoters of the reform, it was learned that the main task of the civil service's reform was, in the words of the respondent, "to strengthen the responsibility of [civil servants] and to secure the results of activity $^{\prime 44}$. Another officer, who had high duties in the Office of Prime Minister, specified that the main objective of reforms was to relate the work remuneration system of civil servants with the results of activity, because according one more representative of this institution, "little work is done in civil service to achieve some particular result. Usually work is just for working [...]. In the beginning of each year the good work results of the [employees] have to be determined, included into the official agreements, and rewarded by certain bonuses" ${ }^{\prime 45}$. The interview with the promoters of reforms creates an impression that the performance management in the Lithuanian civil services should be strengthened starting with the individual level. In other words, the individual annual objectives-goals have to be agreed with each employee in the beginning of every year, and if these objectives are achieved, the variable part should be added to the salary of civil servants for the results of activity. Since 2011 the new official assessment system has operated in Lithuania when each civil servant discusses annual objectives of activity with the direct supervisor in the beginning of each year, but the second condition - salary depending on results - has not been implemented. The old order remains when the civil servant receives "very good" evaluation and approval from direct supervisor in special assessment commissions and thus his/her official category may rise (which automatically leads to increased salary) or the qualification class may be granted. However, this is not a "pure" mechanism of payment for results (although often considered certain variety of such payment) when the variable part of salary is added for certain achieved results. Meanwhile the qualification classes and grounds for them are regarded as a discredited mechanism, which has lost its meaning among the civil servants: "the qualification classes shall be granted once and for all [until the end of the service]. They completely distort the career system because their present values do not induce any objective or sense to pursue a career as when the higher category is granted and the class is lost, the lower salary will be paid"46.

It should be noted that almost half of the respondents related the objectives of the reform with the dimension of orientation to the results. However, these respondents had both positive and skeptical remarks.

\footnotetext{
${ }^{44}$ Interview with the director of department, Office of Prime Minister of the Republic of Lithuania (March 07, 2011).

${ }^{45}$ Interview with the head and the deputy head of the institution, Office of Prime Minister of the Republic of Lithuania (June 20, 2011).

${ }^{46}$ Interview with the top civil servant, Ministry of Energy of the Republic of Lithuania (March 09, 2011).
} 
One respondent of the research recognized the need for changes in civil service, but still had a negative attitude towards the draft Law of Civil Service, because in his opinion, "it [draft law] ended as salad when many products are added without caring whether they are compatible ${ }^{\prime 47}$. He is supported by another participant in the qualitative research, who states that the ideas of that time should be considered radical reform, which would not be useful, as in his opinion, the changes had to be made gradually, starting with the most problematic areas. He implied that the result-based payment should be consolidated primarily: "I think that [the changes in civil service] should have been done gradually, starting with the places, which are the least transparent - opaque salaries, as it is not clear, how they are calculated, and after they are arranged, it would be possible to move on towards assessment procedure, and other stages. ${ }^{\prime 48}$ There were more respondents who had similar opinions. So it is possible to generalize that the ideas of the $15^{\text {th }}$ Lithuanian Government were received critically because of their wide extent, although the result-based initiative was supported. However, no belief in its success was expressed, because it was planned that it would not be applied individually, but among other initiatives, as a means for demonstrating how to improve civil service.

Another group of skeptical respondents saw a possible hazard in the attempts to implant the elements of private business management in civil service. The element of performance management - performance measurement - received the most unfavorable approach, because the respondents doubted whether it is possible to do this in public sector by defining the criteria expressed in quantitative form. This is mostly related to the particularity of work in public sector: "So what are the criteria for evaluation of intellectual work, I don't know [...] They [civil servants] work with the intellectual product, They [civil servants] create rules of the game, create laws, which will implemented at lower branches, thus this [work/activity in the civil service] is an intellectual product." ${ }^{49}$ The participants of the qualitative research mainly identify the activities of public sector with the routine tasks (e.g., preparation of documents), thus they doubt in successful application of quantitative indicators "[...] the formation of tasks and determination of the results' indicators is a very slippery thing" ${ }^{\prime 50}$, because in "manufacture the

\footnotetext{
47 Interview with the head of Unit of the institution, National Paying Agency under the Ministry of Agriculture of the Republic of Lithuania (October 06, 2011).

48 Interview with the civil servant, Ministry of the Interior of the Republic of Lithuania (May 12, 2011).

${ }^{49}$ Interview with the top civil servant, Ministry of Social Security and Labour of the Republic of Lithuania (March 17, 2011).

${ }^{50}$ Interview with the top civil servant, The Ministry of Agriculture of the Republic of Lithuania (July 26, 2011).
} 
product is clear, as well as its manufacturing terms and amounts, while here the product is legal acts, and I would not dare to assess them in numbers" ${ }^{51}$.

Other respondents related the measurement problems of activity in public sector to strategic planning, which does not function well enough and thus complicates the performance measurement, in their opinion. For example, one respondent indicated: "Let us say that last year we had 120 violations, this year 102. So what happened? Is it good or bad? Do we investigate the violations? For this purpose the strategic planning is needed. A serious one. Earlier it was stronger, now it is a little forgotten [...]. The problem, the objective is set, sometimes it is formal, but to measure it $[\ldots]^{\prime \prime 52}$. The statement of this respondent creates the impression that the interrelation between the indicators of objectives and performance is bad and this aggravates the performance measurement process. Thus in order to carry out the successful performance measurement, the "tree of objectives" has to function well, i.e. the objectives dropped down from the top have to match well between themselves, and suit for the programs, projects and indicators. Indeed the other respondent stressed: "The possibilities, strategic plans, priorities and their implementation means have to be clearly approved. Now they sound like "to prepare ten laws". What is the sense? Have any of the prepared ten laws improved the life of at least one Lithuanian resident? There is no such measurement unit and thus it is said: "I have prepared two hundred acts", wonderful, but what is the benefit? It is not known yet.... Thus some work should be done with his measurement." 53

Some respondents approve the integration of management elements of the private sector into the public sector, but "when [the result-based performance management] is transferred mechanically to the civil service, the transfer cannot be always conducted properly" ${ }^{\prime 54}$.

It is interesting to note (in a good sense) that the person appeared among the participants of the qualitative research, who (following his own initiative) stressed that the performance indicators (results) in the public sector have to be orientated not to the dimension of products-output, but to the dimension of effect-outcome: "the results should be measured by the impact made by the institution on budgetary income and satisfaction of society by its actions"

\footnotetext{
${ }^{51}$ Interview with the head of the department, The Ministry of Agriculture of the Republic of Lithuania (July 26, 2011).

52 Interview with top civil servant, Chief Official Ethics Commission of the Republic of Lithuania (May 12, 2011).

53 Interview with the top civil servant, Ministry of Environment of the Republic of Lithuania (March 28, 2011).

${ }^{54}$ Interview with the head of the institution, State budgetary institution under the Ministry of Finance of the Republic of Lithuania (June 02, 2011).

${ }^{55}$ Interview with the head of the institution, State budgetary institution under the Ministry of Finance of the Republic of Lithuania (June 02, 2011).
} 
One more problem became evident during the qualitative research in the context of result-based management - increased administrative loads. Although the respondents agree with the benefit provided by the performance management, but they worry about the "side effect", when too many resources have to be attributed to the result-based management (e.g., time expenditure, human resources) and the activity rather than the set goals becomes an end in itself:

Sometimes I don't understand what we do and sometimes when we strive to achieve as if good goals, we lose a lot, or we declare opposite of what we really do. And with regard to the strategic planning, during the last seminar organized by the Government and Ministry of Finances, the following information was given: it is very good that we have strategic planning, but how we do this is far from being ... we declare that we strive for results, but actually we work only for papers. The strategic planning works on its own and financing on its own, and it has nothing to do with what we receive. From one side, it is because we do not have enough financial resources. In such a case, if you feel patriotic, you work for the account of own leisure, but that plan is somewhere. Earlier we used to work for the result, now we are forced to work for paper, as we have to handle and write so many plans and for no reason. That is the increasing of bureaucracy. As long as everything is not standing on its own, no reforms can help. And strategic planning is a tool, not a goal. I could show you concretely, how we plan: we have to do something. These are the Government's objectives, but one size cannot fit all the institutions. We have to show formally that we are acting. It's ok, but we have to what is prescribed by laws, as well. ${ }^{56}$

Another respondent pointed out that the civil servants regard new order of individual assessment as senseless (because it is difficult to measure routine tasks and because it was implanted too urgently) and causing additional administrative resources: "we have additional work, some additional tasks, but what can I create if I even don't know what he is doing"57.

Finally, it should be noted that the respondents who supported changes in civil service mostly linked their approval with the faulty assessment system of civil servants, which they considered not oriented to results and subjective, because the assessments were carried out not according to the results, but "according to the principle - I know that he works well and I know that he does not work", as it was stated by the top civil servant of one Ministry. ${ }^{58}$

56 Interview with the head of the institution, State budgetary institution under the Ministry of Environment of the Republic of Lithuania (June 07, 2011).

${ }^{57}$ Interview with the civil servant, National Land Service under the Ministry of Agriculture of the Republic of Lithuania (September 26, 2011).

${ }^{58}$ Interview with the top civil servant, Ministry of Foreign Affairs of the Republic of Lithuania (March 10, 2011). 


\section{RESULTS OF THE QUALITATIVE RESEARCH: ATTITUDES OF POLITICIANS TOWARDS THE COMPONENTS OF PERFORMANCE MANAGEMENT WITHIN THE CONTEXT OF REFORM OF CIVIL SERVICE}

As could have been expected, the politicians find it very important that the result-based performance management would start from the implementation of their visions (it is good if they include the obligations to the citizens and needs expressed by the society) by transforming them to clear underlying goals of the activity and linking the assessment criteria and underlying areas with the financial resources:

It was the time when the Minister was not managing the budget. He was simply introduced to it by people with long work experience, or some tables used to come from the Ministry of Finances. The clerks working long in the ministry used to comment those tables to the minister and his team and they were approved essentially like this. Thus it cannot be said anything about some progress, positive change or novelties. So we consider that the real positive thing is the political team that comes with its own vision, strategic attitudes and first of all handles the budget according to the strategic direction (their recommended number should not exceed 6). However, I think that each minister should know what is the most important within his competence - to set the priorities and direct there the most important finances. That is exactly what is happening at present - the minister sets the priorities in presence of the political team, discussing them with the ministerial apparatus, and then the person is put on his legs and not on his head, as it used to be previously, in my opinion. How is it possible to implement the political provisions or reforms if the table, template and budget are already set and nothing can be moved. ${ }^{59}$

Other statements of the politicians who have participated in the research allow for the conclusion that the politicians find it important to have objectives implemented by splitting them into smaller goals of the institutions of public administration. However, the results should be assessed not through the evaluation of each individual civil servant. It should be directed more towards the team's results, i.e. the results of the institution's structural unit (for example, department), probably because it would make easier for the politicians to understand, how their strategic challenges were responded: "[...] I would prefer the results of the institutional structure, not of the individual officers, which should be followed by the results of separate units. Then the manager would have certain task and his army, and thus he will have to dislocate it so that the battle and war were won $[\ldots]^{\prime 60}$

\footnotetext{
${ }^{59}$ Interview with the Ministry of Republic of Lithuania (June 08, 2011).

${ }^{60}$ Interview with the head of the Committee of the Seimas [the Parliament] of the Republic of Lithuania (March 10, 2011).
} 
(Interview with the manager of the committee of the Lithuanian Seimas, 10/03/2011).

It should be noted that the participating politicians found the element of performance management-performance measurement-relevant: they were especially worried about the situation of "artificial creation of indicators" ${ }^{61}$. The earlier research also revealed that it is characteristic of the Lithuanian organizations of public administration. In 2008 researcher Vitalis Nakrošis noted that "some annual plans of assessment criteria are deliberately planned as pessimistic and smaller so that their complete implementation or even transcendence was secured" and presented the case of the Ministry of Education and Science, where the plan of assessment criteria was implemented by $271,6 \%(!){ }^{62}$

\section{DO THE PARTIES' PROGRAMS REFLeCt THE INITIATIVES OF RESULT-BASED PERFORMANCE MANAGEMENT?}

When the program of the largest party of the current coalition (of the $16^{\text {th }}$ Government of Republic of Lithuania) in power - Lithuanian Social Democratic Party (LSDP) - for election to the Seimas for the term 2012-2016 is analyzed, it is possible to notice that the result-based management dimension in public sector is left almost unmentioned in the opening: only one paragraph is given to mention abstractly that "the State management system [...] has to operate effectively and transparently and to have the society's trust" ${ }^{\prime \prime 3}$. The titles of two other parts of this program - "Public Administration" and "Civil Services" - give hope that certain components of performance management may be presented there. However, the part "Public Administration" is limited to abstract theses, which also do not speak about application of the elements of result-based performance management in public sector. Meanwhile, it is possible to notice some fragmentary references to the implantation of the elements of performance management in civil service in the chapter "Civil Service". The statement in the program that "the assessment procedure and results of the civil servants could be more effectively used to plan the career of public servants (promotion) and to motivate them to perform quality work" contains some hints about usage of the information on performance (results) on the individual level for studying purpose, but the information would be directed only towards the inducement of civil servants. Thus it is specified in the next statement that the salary of civil servants should be more related to work results. Therefore the LSDP party does not suggest a more developed model of

\footnotetext{
${ }^{61}$ Interview with the Ministry of Republic of Lithuania (June 08, 2011).

62 Vitalis Nakrošis, supra note 2, p. 21-22.

63 The Election Programme "People - First" 2012 of Lithuanian Social Democratic Party // http://Isdp.It/apie-partija/programos/partijos-programa (accessed November 1, 2013).
} 
performance management. It simply mentions fragmentarily the cries of performance management made famous by the $15^{\text {th }}$ Lithuanian Government: increase of effectiveness and linkage of salary to the activity results. However, there is also the usage of information of activity results for inducement of civil servants on the individual level when the salary is received not only for results but also for promotion.

The part of the Labour Party's (hereinafter LP) program "State Management, Regional Policy and Self-Government" ${ }^{\prime 64}$ contains the attempt to create the performance management system by calling it a "system of long-term strategic planning, financing and management"; however, there is no explanation of the system provided, neither what is supposed to be changed nor what the benefits of such changes could be. It is stated in one of the clauses (statements) of the subtopic of the program that "we will make the activity of State and municipal institutions and the decisions they make public" and that "the managers of the State institutions will have to inform the society regularly about the institution's activity". So the impression is made that the information on performance will be used externally for the purpose of accounting to the society. However, it was not explained in more detail what results (information) would be presented (if any), and in what frequency, etc.

The election program of the other parliamentary party "Order and Justice" ${ }^{65}$ (hereinafter OJP) of the year 2012 "The Third Republic" had no references to performance management. There is no data on the result-based performance management in the election programme 2012 of the party "Electoral Action of Poles in Lithuania"66 (hereinafter EAPL), as well.

\section{CONCLUSIONS}

The results of the qualitative research revealed that civil servants received the ideas of the $15^{\text {th }}$ Lithuanian Government to reform public sector critically because of their wide extent, although the result-based initiative was supported. However, no belief in its success was expressed, because it was planned to be applied not individually, but, among other initiatives, as a means to improve civil service. On the other hand, part of the respondents did not approve implementation of the elements of private business management in civil service, for example performance

\footnotetext{
64 The Election Programme 2012 of Labour Party //http://www.darbopartija.It/rinkimai-2012/programa2012/\#valstybes-valdymas-regionine-politika-ir-savivalda (accessed November 1, 2013).

65 The Election Programme "The Third Republic" 2012 of "Order and Justice" Party // http://www.tvarka.It/index.php?id=7293 (accessed November 1, 2013).

66 The Election Programme 2012 of "Electoral Action of Poles in Lithuania" Party // http://www.awpl.It/index.php?option=com_content\&view=article\&id=366:program-wyborczy-akcjiwyborczej-polakow-na-litwie-\&catid=42:aktualia\&Itemid=59\&lang=It (accessed November 1, 2013).
} 
measurement, as the respondents doubted whether it is possible to do this in the public sector by defining the criteria expressed in quantitative form. The problems of performance measurement of the public sector were related to the strategic planning, which in their opinion does not function well enough; thus it complicates the performance measurement. The interrelation between the indicators of objectives and performance is also bad and this aggravates the performance measurement process. One more problem became evident during the qualitative research in the context of result-based management - increased administrative loads. Although the respondents agree with the benefit provided by the performance management, they worry about the "side effect", when too many resources have to be attributed to the result-based management (e.g., time expenditure, human resources) and the activity rather than the set goals becomes an end in itself. However, performance management would be acceptable to the civil servants because of the changes in assessment system, as they are disappointed in the present subjective assessment procedure that is not orientated to the results.

Meanwhile the results of the qualitative research revealed that the politicians find it very important that the result-based performance management would start from the implementation of their visions by transforming them to clear underlying goals of the activity and linking the assessment criteria and underlying areas with the financial resources. However, the results should be assessed not through the evaluation of each individual civil servant. It should be directed more towards the team's results, probably because it would make it easier for the politicians to understand the reactions to their strategic challenges.

The analysis of the programs of present parties in power for election to the Lithuanian Seimas (term of 2012-2016) reflected that the Lithuanian parties pay little attention to the adaptation and development of result-based management in the Lithuanian public sector. For example, the small partners of the coalition Government (OJP, EAPL) do not provide any initiatives of performance management in their programs at all. The parties that have received the greater support of the electors (LSDP, LP) mention abstract elements of performance management in their programs, but these are more episodic statements, which are not presented in more detail, and they do not provide any systematic approach as to how performance management should be adapted or implemented in the public sector of the Republic of Lithuania. 


\section{BIBLIOGRAPHY}

1. Bevan, Gwyn, and Christopher Hood. "What's Measured is What Matters: Targets and Gaming in the English Public Health Care System." Public Administration 84 (3) (2006): 517-538.

2. Buss, Terry F., Nathaniel J. Buss, and Evan Hill. "Evidence in Public Management: A Comparative perspective": 119-153. In: Anna Shillabeer, Terry F. Buss, and Denise M. Rousseau, eds. Evidence-Based Public Management: Practices, Issues, and Prospects. New York: M. E. Sharpe, 2011.

3. Civinskas, Remigijus. "Can a Senior Civil Servant Adapt to Managing by Contract? Reform and Civil Servants' Preferences in Lithuanian Government." Baltic Journal of Law \& Politics 4 (2) (2011): 154-186.

4. Dull, Matthew. "Why PART? The Institutional Politics of Presidential Budget Reform." Journal of Public Administration Research and Theory 16 (2006): 187-215.

5. European Commission's Press Release "Road Safely: EU Reports Lowest Ever Number of Road Deaths and Takes First Step Towards an Injuries Strategy" // http://europa.eu/rapid/press-release_IP-13-236_en.htm (accessed November 1, 2013).

6. "Expect Federal Programs to Perform Well, and Better Every Year." Expectmore.gov [Bush Administration's website for PART initiative; it is currently no active and has not been updated since president Obama refused PART] //

http://georgewbush-whitehouse.archives.gov/omb/expectmore/about.html (accessed October 22, 2013).

7. Frisco, Velda, and Odd J. Stalebrink. "Congressional Use of the Program Assessment Rating Tool." Public Budgeting \& Finance 28 (2) (2008): 1-19.

8. Gudelis, Dangis. Savivaldybiu veiklos matavimo modeliai ir ju igyvendinimo galimybès Lietuvoje (Municipal Performance Measurement Models and Opportunities of their Implementation in Lithuania). Doctoral dissertation. Vilnius: Mykolas Riomeris University, 2007 [in Lithuanian].

9. Hammerschmid, Gerhard, Steven Van de Walle, and Vid Stimac. "Internal and External Use of Performance Information in Public Organizations: Results From an International Survey." Public Money \& Management 33 (4) (2013): 261-268. 
10. Ho, Alfred. "GPRA After A Decade: Lessons From The Government Performance and Results Act and Related Federal Reforms." Public Performance \& Management Review 30 (3) (2007): 307-311.

11. Kaselis, Mindaugas, and Saulius Pivoras. "Valstybejs tarnautoju veiklos vertinimas pagal rezultatus: taikymo iššūkiai Lietuvoje" (Civil Servants' Performance Assessment by Results: Challenges of Implementation in Lithuania). Viešoji politika ir administravimas (Public Policy and Administration) 11 (1) (2012): 139-152 [in Lithuanian].

12. Moynihan, Donald P. The Dynamics of Performance Management: Constructing Information and Reform. Washington: Georgetown University Press, 2008.

13. Moynihan, Donald P., and Stephane Lavertu. "Does Involvement in Performance Management Routines Encourage Performance Information Use? Evaluating GPRA and PART." Public Administration Review 72 (4) (2012): 592-602.

14. Moynihan, Donald P., and Sanjay K. Pandey. "The Big Question for Performance Management: Why Do Managers Use Performance Information?". Journal of Public Administration Research and Theory 20 (4) (2010): 849-866.

15. Nakrošis, Vitalis. "Reforming Performance Management in Lithuania: Towards Result-Based Management": 53-115. In: B. Guy Peters, eds. Mixes, Matches and Mistakes: New Public Management in Russia and the Former Soviet Republics. Budapest: Open Society Institute, 2008.

16. Nakrošis, Vitalis. Strateginis valdymas Lietuvoje: ar turime rezultatu vyriausybę? (Strategic Management in Lithuania: Do We Have Result-Based Government?). Vilnius: Vilniaus universitetas, 2008 [in Lithuanian].

17. Nakrošis, Vitalis, and Žilvinas Martinaitis. "Introduction": 45-49. In: Vitalis Nakrošis and Žilvinas Martinintis, eds. Lithuanian Agencies and Other Public Sector Organisations: Organisation, Autonomy, Control and Performance. Vilnius: Vilnius University, 2011.

18. Newcomer, Kathryn, and F. Stevens Redburn. "Driving Improvement in Federal Policy Outcomes: Lessons for a New President": 259-268. In: Anna Shillabeer, Terry F. Buss, and Denise M. Rousseau, eds. Evidence - Based Public Management: Practices, Issues, and Prospects. New York: M. E. Sharpe, 2011.

19. Nomm, Kulli, and Tiina Randma-Liiv. "Performance Measurement and Performance Information in New Democracies: A Study of the Estonian Central Government." Public Management Review 14 (7) (2012): 859-879. 
20. Pivoras, Saulius. "Konkursinès atrankos i Lietuvos valstybès tarnyba tobulinimas gero valdymo iššūkiu perspektyvoje" (Improving the Competitive Selection for Civil Service in Lithuania with Respect to the Challenges of Good Governance). Viešoji politika ir administravimas (Public Policy and Administration) 11 (3) (2012): 473-487 [in Lithuanian].

21. Radin, Beryl A. Challenging Performance Movement: Accountability, Complexity and Democratic Values. Washington: Georgetown University Press, 2006.

22. Rauleckas, Rimantas, et al. "Public Administration Reforms during Fiscal Crisis in Lithuania: Perceptions of Senior Civil Servants." Viešoji politika ir administravimas (Public Policy and Administration) 12 (3) (2013): 350-362.

23. Redbum, F. Stevens, Robert J. Shea, Terry F. Buss, and Ednilson Quintanill. "Performance-Based Management: How Governments Can Learn from Experience": 3-18. In: F. Stevens Redbum, Robert J. Shea, and Terry F. Buss, eds. Performance Management and Budgeting: How Governments Can Learn from Experience. New York: M. E. Sharpe, 2008.

24. The President's Management Agenda (2002). Office of Management and Budget //

http://www.whitehouse.gov/sites/default/files/omb/assets/omb/budget/fy200 2/mgmt.pdf (accessed September 1, 2012).

25. Van Dooran, Wouter. "Nothing New Under the Sun? Change and Continuity in the Twentieth-Century Performance Movements": 11-23. In: Wouter Van Dooran and Steven van de Walle, eds. Performance Information in the Public Sector. Basingstoke: Palgrave Macmillan, 2008.

26. Van Dooran, Wouter. Performance Measurement in the Flemish Public Sector. Doctoral dissertation. Leuven: Katholike Universiteit, 2006.

27. Van Dooran, Wouter, Geert Bouckaert, and John Halligan. Performance Management in the Public Sector. London and New York: Routledge, 2010.

28. Van Thiel, Sandra, and Frans L. Leeuw. "The Performance Paradox in the Public Sector." Public Performance \& Management Review 25 (3) (2002): 267281.

29. Visockytè, Ernesta. "Civil Service and Civil Servants in Lithuania: Issues of Regulation and Status." Baltic Journal of Law \& Politics 4 (2) (2011): 125-153.

30. Visockytè, Ernesta. "Lietuvos valstybès tarnybos reformos poreikis valstybès tarnautoju požiūriu" (The Need for Civil Service Reform in Lithuania: Civil Servants' Position). Viešoji politika ir administravimas (Public Policy and Administration) 11 (3) (2012): 488-501 [in Lithuanian].

31. VORT project. Government of the Republic of Lithuania // 
http://www.Irv.It/en/activities/vort-project/vort-project1/ (accessed November 23, 2013).

32. West, William F. Program Budgeting and the Performance Movement: The Elusive Quest for Efficiency in Government. Washington: Georgetown University Press, 2011.

33. Williams, Daniel W. "Measuring Government in the Early Twentieth Century." Public Administration Review 63 (6) (2002): 643-659.

\section{LEGAL REFERENCES}

1. Lietuvos Respublikos vyriausybès nutarimas dèl valstybès tarnybos tobulino koncepcijos patvirtinimo (Resolution of the Government of the Republic of Lithuania on the Authorization of the Civil Service Improvement Strategy Conception). Resolution of the Government of the Republic of Lithuania No. 715 (June 2, 2010) //

http://www3.Irs.It/pls/inter3/dokpaieska.showdoc_l?p_id=375123\&p_query= \&p_tr2 $=$ (accessed November 25, 2013) [in Lithuanian].

2. Lietuvos Respublikos vyriausybès projektas "Valstybès tarnybos tobulinimo koncepcija" (Project of the Government of the Republic of Lithuania of the Civil Service Improvement Strategy Conception). Project by the Government of the Republic of Lithuania No. 10-695-01 (February 25, 2010) // http://www.muitinesprofsajunga.It/index.php/skelbimai-praneimai/150valstybs-tarnybos-tobulinimo-koncepcijos-projektas (accessed November 25, 2013) [in Lithuanian].

3. The Election Programme 2012 of "Electoral Action of Poles in Lithuania" Party //

http://www.awpl.It/index.php?option=com_content\&view=article\&id=366: pro gram-wyborczy-akcji-wyborczej-polakow-na-litwie-

\&catid=42: aktualia\&Itemid=59\&lang =It (accessed November 1, 2013) [in Lithuanian].

4. The Election Programme 2012 of Labour Party // http://www.darbopartija.It/rinkimai-2012/programa-2012/\#valstybesvaldymas-regionine-politika-ir-savivalda (accessed November 1, 2013) [in Lithuanian].

5. The Election Programme "People - First" 2012 of Lithuanian Social Democratic Party // http://lsdp.It/apie-partija/programos/partijos-programa (accessed November 1, 2013) [in Lithuanian]. 
6. The Election Programme "The Third Republic" 2012 of "Order and Justice" Party // http://www.tvarka.It/index.php?id=7293 (accessed November 1, 2013) [in Lithuanian]. 